\title{
Nèščiųjų anafilaksija
}

\author{
Adelè Druktenytè, Brigita Šitkauskienè \\ LSMU MA Pulmonologijos ir imunologijos klinika
}

Reikšminiai žodžiai: anafilaksija, něštumas, gimdymas, gaivinimas.

Santrauka. Anafilaksija něštumo metu yra reta, tačiau labai pavojinga būklè ir něšciajai, ir vaisiui. Něštumo pradžioje anafilaksijos etiologiniai veiksniai panašūs į bendrojoje populiacijoje anafilaksiją sukeliančius veiksnius, o něštumo pabaigoje ir gimdymo metu dažniausias anafilaksiją sukeliantis veiksnys yra vaistai (ypač penicilinas bei kiti beta laktaminiai antibiotikai). Něščiujų anafilaksijos diagnostika remiasi ịprastiniais anafilaksijos diagnostikos kriterijais, tačiau yra ir tik nėščiosioms būdingu klinikinių simptomų: intensyvus genitalijų niežejimas, nugaros apatinès dalies skausmas, skausmingi gimdos susitraukimai, priešlaikinio gimdymo požymiai. Be dažniausių anafilaksijai būdingų komplikacijų, něštumo metu galimi negrǐžtami vaisiaus CNS pažeidimai, didesnė perinatalinės mirties rizika. Straipsnyje apžvelgiami pirmosios pagalbos, teikiamos néčiajai anafilaksijos metu, ypatumai. Tokiais atvejais teikiant pagalbą būtina užtikrinti ne tik nèščiosios gyvybines funkcijas, bet ir stebėti vaisiaus būklę.

\section{IVADAS}

Néščiujų anafilaksija reta, bet labai pavojinga būklè, galinti sukelti sunkių komplikacijų ir néčiajai, ir ypač vaisiui. Jos dažnumas $-2,7-3$ atvejai iš 100 tūkst. gimdymų $[2,10]$, o sunkios komplikacijos siekia iki 40 proc. [2]. Nepaisant placentos barjerinès funkcijos, kuri apsaugo vaisiu nuo motinos imunoglobulino (Ig) E antikūnu patekimo ir tiesioginio pažeidimo, anafilaksijos metu kylanti motinos hipoksija ir hipovolemija sutrikdo gimdos aprūpinimą krauju, vaisiaus organizme vystosi ryškūs metaboliniai pokyčiai, atsiranda distreso požymiu ir něštumą dažnai tenka užbaigti cezario pjūvio operacija $[2,4,12]$. Apie 74 proc. nèštumų, pasireiškus anafilaksijai, yra užbaigiami atliekant cezario pjūvị [12].

\section{ETIOLOGIJA}

Néštumo pirmaisiais trimestrais anafilaksiją sukeliantys veiksniai dažniausiai yra tokie patys kaip ir bendrojoje populiacijoje. Pagal anafilaksijos išsivystymo mechanizmą veiksniai gali būti skiriami i susijusius su IgE ir nesusijusius su IgE [8]. Su IgE susiję veiksniai - tai dažnai alergiją sukeliantys maisto produktai (žuvis bei kitos jūros gèrybès, riešutai, pienas, kiaušiniai), medžiagos, patenkančios ¡ kraują igèlus vabzdžiams (širšèms, bitèms, vapsvoms, kai kurioms skruzdèms), latekso gaminiai, retai biologinès medžiagos (vakcinos, monokloniniai antikūnai), vaistai (penicilinas ir kiti beta laktaminiai antibiotikai) $[1,8$, 29]. Su IgE susijusiuc veiksnių sukelta anafilaksija sudaro daugiau nei 70 proc. visų néščiųju anafilaksijų atvejų [22]. $\mathrm{Su}$ IgE nesusiję veiksniai dažniausiai yra vaistai (nesteroidiniai vaistai nuo uždegimo, didelès molekulinès masès dekstranas (retai), labai retai - intraveninis Ig). Taip pat labai retai anafilaksijos priežastis gali būti ir tiesiogiai putliụjų ląsteliụ ir bazofilų degranuliaciją sukeliantys fiziniai veiksniai (šaltas oras, šaltas vanduo, karštis, UV spinduliai). Galima ir idiopatiné anafilaksija $[1,2,6]$.

Něštumo pabaigoje bei gimdymo metu ištinkančios anafilaksijos priežastys labiau susijusios su pačiu néštumu, gimdymu ir jų priežiūra. Šiuo laikotarpiu anafilaksiją dažniausiai sukelia vaistai. Antibiotikai, pvz., penicilinas ar kiti beta laktaminiai, kurie skiriami apsaugoti naujagimį nuo infekcijos ar atliekant cezario pjūvĭ, užima pirmą vietą tarp anafilaksiją sukeliančių veiksnių [12, 13]. Skiriant peniciliną (ypač injekcijų forma) něšciosioms ar gimdyvėms kyla 5 anafilaksijos atvejai iš 10 tūkst. penicilino skyrimo atvejų [13].

Nèštumo metu anafilaksijai pasireikšti įtakos gali turèti ir anemijai ar stipriam kraujavimui gydyti skiriamos kraujo transfuzijos, kiti kraujo produktai ar geležies preparatai $[2,19]$.

Néščiųjų anafilaksiją gali sukelti ir vietiškai veikiantys anestetikai, gimdymui skatinti skiriami oksitocinas, B grupès vitaminai, radiokontrastinès medžiagos [2]. Atliekant akušerines-ginekologines procedūras néščiosios yra labiau linkusios $\mathfrak{i}$ anafilaksines latekso sukeliamas reakcijas nei ne néščios moterys [12].

\section{NĖŠČIOSIOS KLINIKINIAI ANAFILAKSIJOS SIMPTOMAI}

Anafilaksijai nèštumo metu būdingas intensyvus genitalijų niežèjimas, nugaros apatinès dalies skausmas, skausmingi gimdos raumenu susitraukimai, priešlaikinio gimdymo požymiai $[1,2]$. Šie simptomai gali kilti dèl staigios putliụju ląstelių, kuriu gausu gimdoje bei makštyje, degranuliacijos $[3,30]$. Išsiskyręs histaminas, prostaglandinai bei kitos 
biologiškai aktyvios medžiagos skatina gimdos raumenų susitraukimą [31]. Retai néščiosios nurodo ir neịprastą simptomą - metalo skoni burnoje [2].

Kiti nėščiųjų anafilaksijos požymiai (1 lentelè) yra tokie patys kaip îprastiniai pasireiškiantys ištikus anafilaksijai: odoje ir gleivineje - 80-90 proc., viršutiniuose ir apatiniuose kvépavimo takuose - iki 70 proc., širdies ir kraujagysliu sistemoje - apie 45 proc., virškinimo trakte apie - 45 proc., centrinejje nervų sistemoje (CNS) - apie 15 proc. [1].

\section{VAISIAUS PAŽEIDIMO MECHANIZMAS IR KLINIKA}

Placenta atlieka barjerinę funkciją, todèl IgE antikūnai pro ją patekti iš motinos ị vaisių negali ir taip vaisius iš dalies apsaugomas nuo alerginès reakcijos [3, 4]. Kai nėščiajai kyla anafilaksija, vaisius gali būti pažeidžiamas trejopai:

- Dèl motinos hipoksemijos sumažejejusio vaisiaus aprūpinimo deguonimi;

- Dèl hipotenzijos sumažèjusios gimdos kraujotakos ir sumažéjusio deguonies patekimo ì vaisių;

- Dèl atsiradusios alkalozès, skatinančios vazokonstrikciją ir bloginančios gimdos kraujotaką, padidejusio motinos hemoglobino afiniteto deguoniui ir dèl to sumažejuusio deguonies tiekimo vaisiui [3].

Vaisius yra itin jautrus pablogejjusiai kraujotakai, todèl greitai isijungia kompensaciniai mechanizmai ir vaisiaus kraujotaka centralizuojama - ji nukreipiama i gyvybinius organus (smegenis, širdị, antinksčius) [9]. Dẻl sumažèjusios periferinès kraujotakos ir oksigenacijos susilpnèja ar išnyksta vaisiaus judesiai. Vaisiaus $\mathrm{pH}$ yra palaikomas buferiniu sistemų [28]. Kai kompensaciniai mechanizmai išsenka, aerobinis metabolizmas keičiasi $\mathfrak{i}$ anaerobinị ir palaipsniui vystosi metabolinè acidozé, kuri progresuoja, kyla asfiksija, vystosi vaisiaus hipoksinè-išeminè encafalopatija, negrịžtami CNS pažeidimai, perinatalinè mirtis [2, 9, 20, 28].

\section{BAIGTYS}

Anafilaksijos metu sustojus nėščiosios širdies veiklai, skubiai atlikus cezario pjūvio operaciją ir naujagimiui gimus per 5 minutes, apie 90 proc. naujagimių CNS būna nepažeista, tačiau jei ši procedūra užtrunka 15 minučiu ar ilgiau, naujagimių, kuriems CNS nepažeista, būna mažiau nei 60 proc. [2].

Tarptautinejje literatūros apžvalgoje aprašomi 28 nẻščiųjų anafilaksijos atvejai, ịvykę 2008 metais [3]:

- motinų mirties atvejų nebuvo;

- gimdymas iki 32 néštumo sav. - 6 atvejai;

- perinataliné mirtis - 4 atvejai;

- 9 naujagimiams nustatyta neurologiniuc sutrikimų, trys jų buvo mažesnio nei 32 sav. gestacinio amžiaus;

- epinefrino skirta tik 12 iš 28 néščiųjų; šių 12 motinų 6 naujagimiai gimé sveiki, 4 turèjo neurologiniu pažeidimų, 2 mirè.

\section{GYDYMAS}

Pagrindiniai nėščiųjų anafilaksijos gydymo principai yra tokie patys kaip ir iprastai gydant anafilaksiją. Tačiau, atsižvelgiant ị anafilaksijos keliamą grèsmę vaisiui, gydymas turi kai kurių ypatumų:

\begin{tabular}{|c|c|}
\hline $\begin{array}{l}\text { Organai/ } \\
\text { sistemos }\end{array}$ & Simptomai \\
\hline $\begin{array}{l}\text { Oda, } \\
\text { gleivinès }\end{array}$ & $\begin{array}{l}\text { Išplitusi eritema, odos ir gleivinių niežèjimas (ypač } \\
\text { genitalijų), pūkšlès, angioedema (liežuvio, periorbita- } \\
\text { linė edema) }\end{array}$ \\
\hline $\begin{array}{l}\text { Kvėpavimo } \\
\text { takai }\end{array}$ & $\begin{array}{l}\text { Nosies niežèjimas, užgulimas, rinorèja, čiaudulys, } \\
\text { gerklės niežèjimas, balso pokyčiai, kosulys, švokš- } \\
\text { timas, dusulys, dažnas paviršutiniškas kvèpavimas, } \\
\text { cianozè, kvėpavimo sustojimas }\end{array}$ \\
\hline $\begin{array}{l}\text { Virškinimo } \\
\text { traktas }\end{array}$ & $\begin{array}{l}\text { Pilvo skausmas, pykinimas, vėmimas, disfagija, pagreitè- } \\
\text { jusi peristaltika ir išmatų ar šlapimo nelaikymas, diarejja }\end{array}$ \\
\hline $\begin{array}{l}\text { Širdies ir } \\
\text { kraujagys- } \\
\text { lių sistema }\end{array}$ & $\begin{array}{l}\text { Krūtinès skausmas (dèl išemijos), tachikardija, bra- } \\
\text { dikardija (retai), aritmijos, širdies plakimo pojūtis, } \\
\text { hipotenzija, alpimas, šokas, infarktas }\end{array}$ \\
\hline $\begin{array}{l}\text { Centrinè } \\
\text { nervuc } \\
\text { sistema }\end{array}$ & $\begin{array}{l}\text { Galvos skausmas, svaigulys, nerimas, regos sutrikimai, } \\
\text { sąmonès praradimas }\end{array}$ \\
\hline $\begin{array}{l}\text { Gimda } \\
\text { ir jos pri- } \\
\text { klausiniai }\end{array}$ & $\begin{array}{l}\text { Skausmingi gimdos susitraukimai, priešlaikinio } \\
\text { gimdymo požymiai }\end{array}$ \\
\hline
\end{tabular}

2 lentelè. Būklès, kurių klinikiniai simptomai panašūs i anafilaksijos ir kurias reikètų diferencijuoti néštumo metu $[3,8]$

- Plaučiuc embolija

- Embolija vaisiaus vandenimis

- Plaučiuc edema

- Astmos priepuolis

- Svetimkūnio aspiracija

- Mitralinè stenozé

- Miokardo infarktas

- Preeklamsija

- Spinalinès blokados, vietiniu anestetikų sukelta hipotenzija

- Hipoglikemija

- Epiglotitas

- Paveldima angioedema

- Isterijos priepuolis

1. Pirmiausia būtina laiku atpažinti anafilaksiją. Nėščiųjų anafilaksiją reikia atskirti nuo kitų būklių, kurių klinikiniai požymiai panašūs ì anafilaksijos (2 lentelè).

2. Kuo greičiau pašalinti anafilaksiją sukèlusi veiksnị.

3. Ivertinti svarbiausius gyvybinius rodiklius: kvejpavimo taku praeinamumą, kvejpavimo dažnį (KD), ŠSD, AKS, sąmonę.

4. Svarbu, kad néščiajai pirmąją pagalbą teikiančioje komandoje būtų anesteziologas, akušeris-ginekologas bei neonatologas.

5. Adrenalino injekcija i raumenis. Adrenalinas (epinefrinas) turi būti skubiai leidžiamas ì raumenis, rekomenduojama injekcijos vieta - šlaunies išorinè vidurinè dalis. Pirmoji dozè - 0,3 mg $1 \mathrm{mg} / \mathrm{ml}$ koncentracijos tirpalo. Injekcija gali būti kartojama kas 5-15 min., kol būkle pradès gerèti. Daugumai pacienčiu atsakas būna po vienos dviejų dozių. Kontraindikacijų skirti adrenaliną gydant anafilaksiją nèra.

6. Papildomo 100 proc. deguonies $6-8 \mathrm{l} / \mathrm{min}$. inhaliacijos pro kaukę ar intubacija, retais atvejais prireikia tracheostomos.

7. Paguldyti néščiąją ant kairiojo šono mažiausiai $15^{\circ}$ kampu [25] ir pakelti kojas. Néščiajai gulint ant nugaros būtų spaudžiama $v$. cava inferior ir pacientès būklè dar labiau pablogètų. Tai itin svarbu, kai nèštumas yra 20 ar daugiau savaičių. Reikia vengti staigaus pacientés 
3 lentelè. Vaisiaus distreso požymiai [32]

- Pakitęs (padidėjęs ar sumažèjęs) vaisiaus širdies susitraukimų dažnis (ypač sąrèmio metu ar po jo)

- Sumažèjęs ar išnykęs vaisiaus širdies susitraukimų variabiliškumas

- Vèlyvosios deceleracijos

atsistojimo ar atsisedimo, kuris gali sukelti ortostatinę hipotenziją, dar labiau bloginančią būklę.

8. Pakankamo kiekio ir greita skysčių infuzija ị veną. Turètú būti skiriama $5-10 \mathrm{ml} / \mathrm{kg} \mathrm{NaCl} 0,9$ proc. tirpalo per 5-10 min. Minimalus néščiosios sistolinis kraujo spaudimas turètų būti ne mažesnis nei $90 \mathrm{~mm} \mathrm{Hg}$, kad būtuc palaikoma placentos kraujotaka.

9. Stebėti néščiosios gyvybines funkcijas: AKS, ŠSD, KD, $\mathrm{SpO}_{2}$. Stebèti vaisiaus būklę kardiotokografu arba skaičiuoti vaisiaus širdies susitraukimų dažnį kas 5 minutes ar dažniau.

10. Jei yra indikacijų, bet kuriuo metu pradèti néščiosios gaivinimą pagal standartinị algoritmą.

11. Esant vaisiaus distreso požymių (3 lentelè), nedelsiant atlikti cezario pjūvio operaciją. Jei vaisiaus gestacinis amžius mažesnis nei 32 savaitès, yra didelè naujagimio mirties rizika dèl neišnešiotumo, tačiau kuo ilgiau tęsiasi vaisiaus hipoksija, tuo didesnẻ neurologinio pažeidimo, prenatalinès mirties tikimybè [2, 3, 23, 24, 25, 27].

\section{IŠVADOS}

Nėščiųjų anafilaksija - reta, greitos diagnostikos ir gydymo reikalinga būklè. Néštumo pradžioje kyla dèl bendrojoje populiacijoje dažniausiai anafilaksiją sukeliančių priežasčių, o nèštumo pabaigoje ir gimdymo metu ją dažniausiai sukelia vaistai, ypač skirti infekcijos profilaktikai. Anafilaksija gali lemti sunkias komplikacijas ir motinai, ir vaisiui, bet paprastai ji pavojingesnè vaisiui. Taigi labai svarbu anafilaksiją laiku diagnozuoti ir tinkamai gydyti, kad būtų išvengta hipoksijos ir hipovolemijos, o reikalui esant, něštumą skubiai užbaigti cezario pjūvio operacija ir taip sumažinti sunkių negrižtamų komplikacijų riziką.

\section{ANAPHYLAXIS IN PREGNANT WOMEN \\ ADELĖ DRUKTENYTEE, BRIGITA ŠITKAUSKIENE \\ DDEPARTMENT OF PULMONOLOGY AND IMMUNOLOGY, MEDICAL ACADEMY, LITHUANIAN UNIVERSITY HEALTH SCIENCES}

Keywords: Anaphylaxis, pregnancy, delivery, resuscitation.

Summary. Anaphylaxis during pregnancy is rare, but serious condition for pregnant woman and her fetus. In the beginning of pregnancy, the common anaphylaxis triggers are similar to the anaphylaxis triggers in the general population. In the end of pregnancy and during delivery, most common causes of anaphylaxis are medications (penicillin and other $\beta$-lactam antibiotic). Diagnosis of anaphylaxis during pregnancy is based on common criteria of anaphylaxis, however, here are typical signs and symptoms for pregnant women, such as intense vaginal itching during pregnancy, low back pain, painful uterine cramps, signs of preterm delivery. Anaphylaxis during pregnancy can cause common complications of anaphylaxis. In addition, during pregnacy it can cause irreversible changes in the central nervous system of fetus and higher perinatal death. This article will review features of first aid for pregnant woman during anaphylaxis. In such cases, it is important to ensure pregnant women vital signs and use fetal monitoring.

\section{LITERATŪRA}

1. F. Estelle R. Simons, A. Sheikh. Anaphylaxis: the acute epizode and beyond. BMJ 2013:346:f602.

2. Simons FE, Schatz M. Anaphylaxis during pregnancy. J Allergy Clin Immunol. 2012; 130(3):597-606.

3. Schatz M., et al. (2013). Anaphylaxis in pregnant and breastfeeding woman. UpToDate. http://cursoenarm.net/UPTODATE/contents/mobipreview. htm?14/50/15137? source=HISTORY (2014 11 15).

4. N. Franklin Adkinson, et al. Asthma and Allergic Diseases during Pregnancy. Middleton's Allergy: Principles and Practice. Elsevier Health Sciences. 2013. p. 951-969.

5. F. Estelle et al. World Allergy Organization Guidelines for the Assessment and Management of Anaphylaxis. World Allergy Organ J. 2011; 4(2):13-37.

6. F. Estelle R.Simons. Anaphylaxis. J Allergy Clin Immunol 2010;125:S161-81.

7. Scott $\mathrm{H}$. et al. Advance in allergic skin disease, anaphylaxis, and hypersensitivity reactions to foods, drugs, and insects in 2013. J Allergy Clin Immunol. 2014; 133:324-334.

8. Richard F. Lockey. (2012) Anaphylaxis: Synopsis. World Allergy Organization. http://www.worldallergy.org/professional/allergic_diseases_center/ anaphylaxis/anaphylaxissynopsis.php (2014 11 25).

9. Blackburn S. Maternal, Fetal, and Neonatal Physiology. Elsevier Health Sciences 2014. P. 167.

10. Hepner DL, et al. Anaphylaxis in the clinical setting of obstetric anesthesia: a literature review. Anesth Analg. 2013;117(6):1357-67.

11. G. Draisci et al. Latex Sensitization. A Special Risk for the Obstetric Population? Anestesiology 2011; 114:565-9.

12. Mulla ZD, et al. Anaphylaxis in the obstetric patient: analysis of a statewide hospital discharge database. Ann Allergy Asthma Immunol. 2010;104(1):55-9.

13. Preventing neonatal group $B$ streptococcal infection. Intrapartum antibiotic prophylaxis in some high-risk situations. Prescrire Int. 2011;20(114):72-7.

14. A. Sengupta, Kohli JK. Antibiotic prophylaxis in cesarean section causing anaphylaxis and intrauterine fetal death. J Obstet Gynaecol Res. 2008;34(2):252-4.

15. A. Berenguer at al. Anaphylaxis in pregnancy: a rare cause of neonatal mortality. BMJ Case Reports 2013.

16. A. Mishra, et al. Fatal anaphylactic reaction to iron in pregnancy. Indian J Pharmacol. 2013; 45(1): 93-94.

17. Ferreres-Garcia K., et al. A case study of anaphylaxis in a pregnant woman. Ginecol Obstet Mex. 2014;82(3):188-93.

18. Galvao TF, et al. Safety of benzathine penicillin for preventing congenital syphilis: a systematic review. PLoS One. 2013;8(2):e56463.

19. Kortenhorst MS, et al. Anaphylaxis after iron dextran administration in a pregnant woman. Ned Tijdschr Geneeskd. 2012;156(48):A5264.

20. Omo-Aghoja L. Maternal and fetal Acid-base chemistry: a major determinant of perinatal outcome. Ann Med Health Sci Res. 2014;4(1):8-17.

21. Parer JT, Livingston EG. What is fetal distress?Am J Obstet Gynecol. 1990;162(6):1421-5; discussion 1425-7.

22. Mertes Pm, Laxenaire MC, GERAP. Anaphylactic and anaphylactoid reactions occurring during anaesthesia in Franze. Ann Fr Anesth Reanim 2004;23:1133-1143.

23. Marc van de Velde, et al. Maternal Critical Care. A Multidisciplinary Approach. Cambridge University Press. 2013. P. 170.

24. Soar J, et al. European Resuscitation Council guidelines for resuscitation 2005. Section 7. Cardiac arrest in special circumstances. Resuscitation 2005;67 Suppl 1:S135-70.

25. Working Group of the Resuscitation Council (UK). Emergency treatment of anaphylactic reactions. Guidelines for healthcare providers. $2008 \mathrm{http}: / /$ www.resus.org.uk/pages/reaction.pdf

26. Anaphylaxis in Pregnancy. University of Oxford. 2012. https://www.npeu. ox.ac.uk/ukoss/current-surveillance/aip

27. Simons FER, et al. World Allergy Organisation guidelines for the assesment and management of anaphylaxis. J Allergy Clin Immunol 2011;127:593. el-22.

28. Stannar L., Bellis A. Maternal anaphylactic reaction to a general anaesthetic at emergency ceasarean section for fetal bradycardia. GBOG. 2001; 108(5):539-540.

29. Bobrow CS, Soothill PW. Causes and consequences of fetal acidosis. Arch Dis Child Fetal Neonatal Ed. 1999 May; 80(3):F246-9.

30. Garfield RE, et al. Structural and functional comparison of mast cells in the pregnant versus nonpregnant human uterus. Am J Obstet Gynecol. 2006; 194(1):261-710.

31. Menzies FM, et al. The role of mast cells and their mediators in reproduc tion, pregnancy and labour. Hum Reprod Update. 2011; 17(3):383-96.

32. Nadišauskienè R., et al. Něščiuju ir gimdyviu kritinès būklès. Kaunas: Vitae Litera, 2009. P. 135. 